\title{
Entrepreneurial overconfidence and its impact upon performance
}

Anna Chiara Invernizzi, Anna Menozzi, Diana Anna Passarani, Dean Patton, Giampaolo Viglia

\begin{abstract}
A hubris theory of entrepreneurship suggests that financial forecasts are often informed by the use of heuristic methods prone to overconfidence. While overconfidence can be advantageous during the start-up phase, it is also linked to overoptimistic forecasts, nonoptimal outcomes and firm failure. This article uses a data set from 203 micro and small firms operating in North West Italy where overconfidence is measured as the difference between budget estimates and actual results for earnings before interest, taxes, depreciation and amortization (EBITDA), owner equity and borrowing costs. These measures are employed to identify the extent of overconfidence by entrepreneurs in their financial forecasts and to analyse any relationship between overconfidence and the characteristics of the entrepreneur and the firm. A probit analysis is employed to investigate any association between overconfident financial forecasts and subsequent firm failure. The results are consistent with the hypotheses, suggesting that the majority of entrepreneurs are prone to overconfident budgetary forecasts that are directly associated with firm failure. Such overconfidence is mitigated by an entrepreneur's level of educational attainment and the use of budgetary controls.
\end{abstract}

\section{Introduction}

The budgeting process underpins an entrepreneur's ability to successfully start and develop a business as forecasting establishes expectations and the resources required to meet such expectations. Inaccurate forecasts can therefore lead to capital investment losses, high financial and inventory costs, poor customer service and inefficient

utilization of productive resources (Diamantopoulos and Winklhofer 1999). Despite its contribution, very few studies consider the accuracy of forecasts in an entrepreneurial context, or the effect this might have on firm performance. Smith, Herbig, Milewicz and Golden, (1996) note a high degree of subjectivity in the forecasts performed by entrepreneurs which they identify as being based upon less complex quantitative forecasting techniques than those used in larger firms. It is suggested (Cassar and 
Gibson 2007) that this subjectivity and use of less complex techniques can induce entrepreneurs to make forecasts that are too optimistic. This is consistent with hubris theory that highlights how overconfidence not only encourages entrepreneurs to start-up firms but to also pursue challenging growth strategies, often in hostile environments with insufficient resources (Hayward, Shepherd and Griffin 2006).

Overconfidence is defined as a cognitive bias that overestimates the probability of a positive outcome to an event compared to the probability of experiencing a negative outcome from the same event (Busenitz and Barney 1994; Ucbasaran, Westhead, Wright, and Flores, 2010; Tipu and Arain 2011). The notion of overconfidence is informed by the literature in the field of cognitive psychology where the term "entrepreneurial cognition" is used to describe the way in which entrepreneurs think and behave (Baron 2004; Mitchell, Busenitz, Lant, McDougall, Morse, Brock Smith, 2002). The advantages and disadvantages associated with an overconfident attitude have been the subject of numerous studies in business research (see Alvarez and Busenitz 2001 and Hmieleski and Baron 2009). While overconfidence can potentially add value during the often-difficult start-up stage (Koellinger, Minniti and Schade 2007; Robinson and Marino 2015), it may also induce entrepreneurs to establish firms without sufficient capital (Hayward, Shepherd and Griffin 2006), overestimate potential (Cassar and Gibson 2007) and fail to recognise poor performance (Shepherd, Wiklund and Haynie 
2009). This article investigates the overoptimistic biases in the context of established firms.

Considerable literature exists on the potential for entrepreneurs to be overconfident in their expectations of firm performance but the majority of this evidence is derived from self-reported attitudinal surveys. In addition, this literature has offered no empirical evidence that identifies an association between overconfidence and firm performance and only limited information on the attributes of the entrepreneur, or firm, that may lead to such behaviour (Ucbasuran et al. 2010). Using published data on the budget forecasts and actual results made available for 2012 by a unique sample of 203 Italian micro and small enterprises, this article addresses two research questions. Are entrepreneurial or firm characteristics related to overconfident attitudes as exhibited in the financial estimations of small firms? Is overconfidence associated with a small firm failure? To address these questions, a novel measure for overconfidence is adopted, computed as the variance between actual and estimated values of three economic indicators: EBITDA (Earnings Before Interest, Tax, Depreciation and Amortization), equity and borrowing costs, derived from comparisons between a firm's balance sheets and financial forecasts over time. We argue that systematic, inflated financial predictions of firm performance signal overconfidence and we operationalise the overconfidence construct as the difference between budgeted and actual performance (Cassar and Gibson 2007; Markovitch, Steckel, Michaut, Philip and Tracy, 2015). 


\section{Theoretical framework}

A hubris theory of entrepreneurship models how more overconfident individuals are more likely to start and develop new ventures and how such ventures are also more likely to fail (Hayward, Shepherd and Griffin 2006). Overconfidence is conceptualized as the overestimation of an event having a positive outcome (Busenitz and Barney 1994; Tipu and Arain 2011) and has been researched with reference to entrepreneurs (Forbes 2005; Ucbasaran et al. 2010; Robinson and Marino 2015) and managers (Sautner and Weber 2009). The analysis of an entrepreneur's psychological behaviour suggests that overconfidence in beliefs and decision-making (Busenitz and Barney 1997) leads to idealistic and unfeasible forecasts (Cassar and Gibson 2007). Such forecasts often rely upon heuristic methods used to make sense of the complex environments faced by entrepreneurs (Baron 1998). Heuristics refer to any approach to problem solving or learning that employs a practical, simplistic and timesaving method not guaranteed to be optimal, but regarded as sufficient for the achievement of immediate goals. One nonoptimal outcome associated with the use of heuristics is the potential for an overconfident attitude to affect the forecasting process. If entrepreneurs are overoptimistic, resource allocation decisions may be compromised, leading to a negative impact upon business performance (Dawson and Henley 2012) and, potentially, business failure (De Meza and Southey 1996; Koellinger, Minniti, and 
Schade 2007). It is recognized that failure can occur when a venture does not meet the expectations of the entrepreneur but, for the purposes of this article, we investigate economic failure identified by insolvency ${ }^{1}$ (Ciampi and Gordini 2009; Ucbasaran et al. 2010; Wennberg and DeTienne 2014; Jenkins and McKelvie 2016). While the closure of the activity may arise from a range of factors (for a discussion see Carter and Van Auken 2006), the emphasis in this article is on the role overconfidence can play in the demise of the firm.

\section{Hypotheses development}

Although hubris theory is well developed in the extant literature, the reason why entrepreneurs appear to exhibit more overconfidence than non-entrepreneurs remains open to debate. One explanation focuses upon the entrepreneur and suggests the act of entrepreneurship attracts individuals that are less rational and more informal in their thinking and, therefore, also more susceptible to the use of heuristics in decisionmaking (Busenitz and Barney 1997). This study draws from previous literature (Levesque and Minniti 2006; Lovallo and Kahneman 2003; Morrell and Ezingeard 2002) in employing personal and firm variables to identify factors that influence the

\footnotetext{
${ }^{1}$ In the Italian legal environment the term "bancarotta semplice" refers to an individual and not to a business. The Italian "Legge fallimentare" (Insolvency Law) sets a threshold on the entrepreneur's or firm's revenues, assets and liabilities to limit the applicability of the "failure" procedures. When the failure requirements are not met, an entrepreneur or a firm incapable of meeting its financial obligations is said to be "insolvent". To avoid confusion, in this paper the term "failure" has been used for identifying enterprises in financial distress that have ceased the activity because of their inability to meet their financial obligations.
} 
level of entrepreneurial overconfidence. Personal variables include the entrepreneur's gender, age, experience and level of education and firm variables include organizational structure and the adoption of any forms of automated information systems. Accordingly, this study presents two groups of hypotheses. The first group (H1, in its multiple dimensions) concerns personal variables; the second group ( $\mathrm{H} 2, \mathrm{H} 3$ and $\mathrm{H} 4)$ refers to firm variables.

(i) Personal characteristics

Differences among entrepreneurs may account for variation in the degree to which they are overconfident and this article takes into account age, gender and education of the entrepreneur. It has been suggested that age is an important variable, with younger entrepreneurs exhibiting more overconfidence (Forbes, 2005; De Jorge Moreno, Castillo, and Masere, 2007). Jovanovic, (1982) and Forbes (2005) present one mechanism that explains this difference showing that the experiential learning of older entrepreneurs diminishes the tendency to overestimate the accuracy of their own knowledge. Forbes (2005) goes on to add that younger entrepreneurs have less time to recognize and correct such biases in themselves. These findings, however, are not entirely consistent with later literature. For instance, Landier and Thesmar (2009) note that repeat entrepreneurs who have started at least one prior business are more 
optimistic than novice entrepreneurs. As a consequence, any relationship between overconfidence and experience is not taken forward and it is instead posited that young entrepreneurs tend to overestimate forecasts for their businesses and attribute chances of success to themselves and chances of failure to others (Cooper, Woo and Dunkelberg 1988).

While both men and women have been shown to display overconfidence, this trait is particularly significant among men, especially when it comes to tasks that are perceived to be in the masculine domain (Beyer and Bowden 1997). In the entrepreneurial context this differing attitude has been observed in connection with bank lending where females, due to issues of self-confidence and a lower propensity for risk, are less likely to apply for bank loans than men (Triechel and Scott, 2006; Coleman, 2000). Freel, Carter, Tagg, and Mason (2012) progress this argument by establishing that there is no difference in approval rates for those female and male owned businesses that apply for loans but that a female led business is less likely to approach a bank with a weak loan application. The implication seems to be that, however misplaced, men are likely to have greater confidence, perhaps overconfidence, in the quality of their business and this is reflected in their propensity to apply for bank loans. This is a gender effect that is bound by structural assumptions and creates constraints to women's choices and options (Marlow and Swail 2014). The argument above contributes to the notion that men are 
more likely to start a business than women (Blanchflower 2004) and, for these ventures, to be more risky (Yardanova and Boshnakova 2011).

The level of educational attainment is also included in the analysis as it is known to influence entrepreneurial leadership (Kropp, Lindsay and Shoham, 2008), contribute to a venture's ability to survive and grow (Colombo and Grilli 2005; Saridakis, Mole and Storey 2008) and have a positive impact upon the degree and quality of planning in small firms (Gibson and Cassar 2002). In terms of overconfidence, previous research found that education can make people more aware of judgmental heuristics and biases (Lichtenstein and Fischoff, 1977). Koellinger, Minniti and Schade (2007) prove that more educated entrepreneurs show lower levels of overconfidence.

The arguments presented identify some grounds for a potential impact of the different personal entrepreneurial characteristics upon levels of overconfidence. This leads into the first hypothesis, in its different specifications:

(H1) Variables associated with entrepreneurial characteristics have a significant effect in explaining entrepreneurial overconfidence:

(H1a) Younger entrepreneurs will exhibit higher levels of overconfidence; 
(H1b) Male entrepreneurs are more overconfident than female entrepreneurs;

(H1c) High levels of educational attainment decrease entrepreneur overconfidence.

(ii) Firm characteristics

Entrepreneurial cognitions are the knowledge structures used to make assessments in starting and developing new ventures. While this concept has often been used with reference to the idiosyncratic knowledge and experiences of the individual, it is pertinent to explore the impact that team-based structures have upon the decision making process of a firm. Houghton, Simon, Aquino, and Goldberg, (2000), for example, find that teams are susceptible to bias and to an illusion of control that could affect their perception of risk. Specifically, two well-known cognitive biases affect teams: group thinking and risk shift. In both these cases homogeneous teams tend to take extreme and riskier decisions (Ruef, Aldrich and Carter 2003; Page-West 2007; Yaniv 2011). In particular, team integration is pivotal and changes to the entrepreneurial team have the potential to significantly affect the quality of the decision making process (Santoni, Fini, Grimaldi, and Wright, 2013). Nevertheless, research (Kugler, Kausel and 
Kocher 2012; Cheung and Palan 2012) has suggested that small groups often make more accurate decisions compared to an individual. Venture teams can broaden networks (Neergaard 2005), point out different perspectives on risks and opportunities (Sniezek and Henry 1989) and assist in gathering new material to counterbalance and challenge the "taken for granted" perspective (Grandi and Grimaldi 2003). As such, there are synergistic gains to be developed from a team of founders that enhances the potential of the new venture through its collective efforts (Colombo and Grilli 2005). This article is able to take advantage of a sample of firms where ownership is concentrated in the hands of a single entrepreneur or shared among an entrepreneurial team to assess the impact such structures have upon the accuracy of budgetary forecasts. This leads to our second hypothesis:

(H2): Overconfidence is more pronounced in firms controlled by a single entrepreneur, rather than an entrepreneurial team.

The use of financial management practices in SMEs across Europe is limited as the costs associated with the commitment of internal resources and the development of management skills is thought to outweigh the contribution such information can make to firm performance (Collis and Jarvis 2002). As a consequence, it is argued that forecasts and budgets are significantly more prevalent among larger firms than small 
and, particularly, micro firms (ACCA 2010; Digital4Executives 2010). Ciambotti, Aureli and Giampaoli (2012) provide some qualitative analyses for Italy and suggest that entrepreneurs consider automated information systems useful for designing effective strategies but are reluctant to fully adopt them as a consequence of myopic cost-benefit evaluations. It is therefore suggested that micro firms are less likely to employ automated information systems to assist with strategic decision-making (Levy, Powell, and Yetton, 2001) and in particular, an integrated accounting or budgetary control system when making financial forecasts (Ismail and King 2014). However, very few businesses are so small or so insular that they can avoid reporting on a regular basis and Collis and Jarvis (2002) suggest that the majority of small firms adopt some accounting practices that include formal methods of planning and control. It is normally a process that is undertaken by the entrepreneur with the support of an accountant. As a consequence, and without a formal accounting or budgetary control system, entrepreneurs often rely on heuristic forecasting methods to provide information to their accountant, which are quicker and cheaper to implement, but prone to cognitive bias that can lead to sub-optimal outcomes (Alvarez and Busenitz 2001; Cassar and Gibson 2007; Hmieleski and Baron 2009).

Following the argument proposed by Morrell and Ezingeard (2002), this article hypothesises that, by adopting and developing information systems, entrepreneurs might obtain significant benefits in terms of efficiency via the reduction of bias in the 
prediction of future activity. It follows that the presence of these systems will weaken the relationship between the individual traits and overconfidence. We therefore formulate the following hypothesis:

(H3) The use of an accounting or budgeting control system reduces overconfidence.

The ability of an entrepreneur to anticipate how the firm will perform in the market is a fundamental component of the decision to start a new business. The connection between entrepreneurial decisions about the future and overconfidence may explain, in part, the high failure rate of new business owners (Koellinger, Minniti and Schade 2007). As the business develops, forecasts will be challenged and the survival of a firm depends upon such forecasts being revised, as argued by Trevelyan (2008). Overconfidence among entrepreneurs may lead to the deployment of heuristic methods that can undermine the planning process both in the initial phases and in any subsequent revisions (Frese 2007; Trevelyan 2008). This article tests whether entrepreneurs who set overconfident forecasts have a higher propensity to fail. While it is understood that failure can be interpreted in a number of ways (Ciampi and Gordini 2009; Ucbasaran et al. 2010; Wennberg and DeTienne 2014; Jenkins and McKelvie 2016), this article follows the perspective that the closure of the activity due to the inability to face financial commitments is a strong indicator of economic failure. Therefore: 
(H4) Overconfidence increases the probability of failure in entrepreneurial firms.

\section{Identifying a measure of entrepreneurial overconfidence}

In the entrepreneurial context, previous literature has employed well-established psychological scales to identify the presence of overconfidence (Busenitz and Barney 1997; Trevelyan 2008). While these scales are tried and tested, they are liable to bias as they rely upon the self-reporting of information by the entrepreneur in response to questions about their own attitudes toward events aimed at measuring their risk propensity. This article presents a novel within-firm measure of overconfidence computed as the difference between estimated and actual results for three variables identified as important in determining a firm's performance (Ciampi and Gordini 2013): EBITDA, a performance measure for the income generated by a firm's core business; owner equity, a proxy for an entrepreneur's holding in a firm; and cost of debt and other related costs borne by a firm taking a loan. This construct is operationalised by assuming that an entrepreneur is overconfident when the forecasts for EBITDA and equity are above the actual figures and forecasts for borrowing costs are below those actually incurred. Data have been conveniently collected to isolate the contribution of automated systems to the generation of forecasts. In some cases, the access to automated information systems could be facilitated by an external accountant whose 
service is limited to the provision of technology in support of the entrepreneur's decision-making process, without substituting for the entrepreneurial judgement in generating forecasts. In line with Forbes (2005), any variations are referred to as higher or lower levels of overconfidence.

\section{Data set and methodology}

The data set includes balance sheet and budget information provided by three Italian chartered accounting firms on 203 micro and small non-financial firms ${ }^{2}$ operating in the Piedmont Region, in North West Italy. Initially, 246 firms were asked to participate in the research but 43 were excluded as they refused to waive the accountant/client privilege. The final sample of 203 firms, 82.5 percent of the initial population, provided data relating to the end of fiscal year 2012 .

Micro and small firms are a very important segment of the Italian economy and while the Small Medium Enterprise (SME) sector as a whole is broadly aligned to the European average, the subset of small and micro firms shows a significant difference in terms of number of enterprises, number of employees and value added contribution (see Table 1). These figures highlight how important the micro sector is to the Italian economy. While there is no comparable dataset for the Piedmont region, figures for

\footnotetext{
${ }^{2}$ According to the Italian National Institute for Statistics (ISTAT), firms with less than 10 employees are defined as "micro enterprises" and firms with 10 to 49 employees as "small firms". As a general practice in empirical works on the Italian context, both micro and small firms are referred to as "small firms" and jointly analyzed as a homogeneous ensemble (see for instance Bartoli, Ferri, Murro and Rotondi, 2014).
} 
employment (45.8 percent of the workforce employed in micro-firms and 21.1 percent small firms) suggests a similar contribution to the regional economy (ISTAT 2013). In Italy, however, this segment of the economy has been hit hardest by the difficult economic circumstances post 2008 with the total stock of small companies falling by 15\% between 2008 and 2013 compared to only 5\% for the SMEs sector as a whole (ISTAT 2013). Given the importance of micro and small firms to the Italian economy and the relatively high documented failure rates (Liedholm and Mead 2013; European Commission 2014), this article offers germane information on the role that overconfidence may play in negatively affecting upon firm performance.

\section{[TABLE 1 ABOUT HERE]}

Despite the prevalence of micro and small firms in the Italian economy, they remain relatively under-researched and little is known about their forecasting and budgetary practices due to the difficulties in accessing raw data. The dataset used in this article is unique and, to our knowledge, no previous study in this research field has used a similar source of data. In testing the hypotheses, three control variables, the age of the firm, its size and the industry sector in which it operates, were considered. The extant literature would suggest that a firm is at greatest risk during its early years due to the "liability of adolescence" (Bruderl and Schussler 1990; Fichman and Levinthal 1991). It is possible 
that a lack of experience, inherent within young firms, leads to overoptimistic forecasts (Coad, Segarra, and Teruel 2013). Firm size has also been found to have an inverse relationship with failure, with larger firms benefiting from a broader range of skills that can mitigate any overconfident attitudes (Jovanovic 1982). In addition, we seek to control for any differences created by sectorial conditions by differentiating between manufacturing, commercial and service industries (Short, McKelvie, Ketchen and Chandler, 2009).

The final dataset contains the following three groups of variables for the year-end 2012 (detailed in Table 2):

(i) Personal characteristics of the entrepreneur: variables related to the basic demographic information for each respondent, including age (agedm and young), gender (gender) and educational level (highedu);

(ii) Firm characteristics: the existence of an accounting or budgeting control system (sys), the industry in which the firm operates (manufacturing, commerce, services), firm size (size, as measured by the number of employees) and age (firmage). The dataset also includes two further characteristics. The first concerns the ownership structure of the firm (entralone), signalling firms in the Italian legal form "Società unipersonale", which only has one shareholder. The second gives information on the viability of the firm in 
the near future, captured by data on failure up to April 2014, designated by the variable failure.

(iii) Entrepreneurial overconfidence: three variables measure entrepreneurial overconfidence, namely the percentage difference of EBITDA (diffebitda), the percentage difference of equity (diffequity) and the percentage difference of borrowing costs (diffbcosts). More precisely, overconfidence is computed as the percentage difference between what was set in the budget (forecast) and what was observed in the final balance sheet (actual), as per equation [1]:

$$
D_{i}=\frac{F_{i}-A_{i}}{A_{i}}
$$

where $F_{i}$ represents the budget forecasted values for firm $i, A_{i}$ represents the balance sheet actual results for the same firm $i$ and $D_{i}$ represents the relative variation of forecast against actual results. Forecasted and actual values refer to EBITDA, equity and borrowing costs so that, in the article, $D_{i}$ is represented by the variables diffebitda, diffequity and diffbcosts. If entrepreneurs do not systematically over- or under-estimate their actual figures, then $D_{i}$ is, on average, equal to zero and forecasts are considered to be unbiased. 
To investigate the determinants of overconfidence in SMEs, we first provide some descriptive statistics about dependent and control variables. Then, we present a regression of the three indicators for overconfidence, diffebitda, diffequity and diffbcosts, over a set of independent variables capturing the characteristics of the entrepreneur and the firm. In addition, the article investigates whether overconfidence in estimating those indicators influences the probability of firm failure (variable failure).

\section{Results}

There are 203 firms in the sample with 102 entrepreneurs having the sole responsibility for the administration and management of the venture, while the remaining 101 firms are controlled by a plurality of shareholders. Firm size ranges between one and twentysix employees and, on average, a firm has been in business for sixteen years, with the youngest firm established for two years and the oldest for forty-five years. Reflecting the literature (Levy et al. 2001; Ismail and King 2014), only forty-nine firms (24 percent of the total) are found to use an accounting or budgetary control system with the majority relying on personal judgment and heuristics. In terms of the personal characteristics of entrepreneurs, 141 out of 203 are male (an accurate reflection of the population according to Bonte and Piegeler 2013), with an average age of forty-eight years and with a diverse level of educational attainment (49 hold a middle school diploma, 99 a high school diploma and 61 an undergraduate or graduate degree). In 
reviewing the potential for entrepreneurs to be overconfident, the findings indicate that over $85 \%$ of forecasts for EBITDA, equity and borrowing costs are better than those actually achieved by the firm.

\section{[TABLE 2 ABOUT HERE]}

Figure 1 represents the average values of the percentage differences between forecasts and actuals for EBITDA, equity and borrowing costs. In the interpretation of results, an increase in the variables diffebitda and diffequity has to be read "negatively", as it implies that the value of EBITDA and equity (that are measures of firm wealth) had been overestimated. Similarly, a decrease in the variable diffbcosts has to be read "negatively", because it implies that borrowing costs had been underestimated in the forecasts. On average, EBITDA is overestimated by 11.6 percent, meaning that there is a substantial difference between the results that were forecasted and those actually attained and that this difference has become evident within a 12-month period between the forecast being made and the final balance sheet being compiled. For example, in absolute values, an average firm expecting to generate an EBITDA of 100,000 euros actually generates an EBITDA of 88,400 euros. This difference is significantly different from zero $(\mathrm{t}(202)=-17.27 ; \mathrm{p}<0.01)$. Similar differences were found for equity, which is overestimated by 8.5 percent $(\mathrm{t}(202)=-13.82 ; \mathrm{p}<0.01)$ and borrowing costs, which 
were 9.1 percent higher in the balance sheet than in the budget $(\mathrm{t}(202)=-14.48 ; \mathrm{p}<$ 0.01). The standard errors of the three variables diffebitda, diffequity, diffbcosts (highlighted by the whiskers in Figure 1) indicate the relative stability of these results across the sample and signifies a bias that is quite homogeneous among firms.

\section{[FIGURE 1 ABOUT HERE]}

Table 3 shows the pairwise Pearson correlations between the dependent, the independent and control variables included in the models. The level of correlation between the variables (agedm, young, gender, highedu, entralone, sys, firmage, size, manufacturing, commerce, services) is always below 0.7 thus suggesting a low risk of multicollinearity.

[TABLE 3 ABOUT HERE]

In order to detect the determinants of overconfidence across a range of firm goals (Anderson 2010), the study presents different regression models for each indicator. Table 4 presents the OLS regression of the measure of overconfidence in the estimation of EBITDA, equity and borrowing costs (dependent variables diffebitda, diffequity and diffbcosts respectively). Overconfidence variables are first regressed upon all the 
personal and firm variables that are expected to influence them on the basis of the previously listed hypotheses, namely young, gender, highedu, entralone, sys, size, firmage (models 1, 3 and 5). Some of these variables turn out not to be significant and subsequently, according to a step-wise regression approach, they are excluded from the analysis in order to narrow the list of sources of overconfidence and isolate their marginal effect (models 2, 4 and 6). All regressions include sector dummies, which turned out not to be significant in the estimates.

\section{[TABLE 4 ABOUT HERE]}

Taking the results shown in tables 3 and 4 together, the evidence to support hypothesis 1 is mixed. Entrepreneur age (H1a) appears to have very little effect upon overconfidence in forecasting financial data, except when the entrepreneur is less than 35 years old (young) and, in that case, only with reference to the forecasting of equity (by 3.2 percent on average). The impact of gender (H1b) and educational attainment (H1c) is more apparent as this is negative and significant in all specifications, all other variables being constant, indicating a deflationary effect on the difference between forecast and actual by 3.4 percent for gender and by 3.2 percent for highedu. When exploring the impact of ownership structure and the single entrepreneur (entralone) upon overconfidence $(\mathrm{H} 2)$, the regression identifies that entralone significantly affects 
borrowing costs only, with a marginal effect of 3 percent. A far stronger effect is found when analysing the impact of control systems (H3), which is significantly found in all specifications and quantified in a reduction of overconfidence by 3.6 percent on average, all other variables being constant.

The evidence from the correlation analysis shows, as expected, a strong positive correlation between the control variables size and firmage, and both potentially have an impact upon overconfidence. Findings from the regression analysis however identify only size as significant, with larger firms exhibiting lower levels of overconfidence for EBITDA and equity (by approximately 0.3 percent, on average). Contrary to expectations, the age of the company (firmage) turns out not to be significant.

The correlation table also provides preliminary evidence that the likelihood of failure (failure) is positively correlated with the existence of a single founder (entralone) and negatively associated with the age of the entrepreneur and the firm (agedm and firmage, respectively). In addition, overconfidence in the forecast of all financial indicators EBITDA, equity and borrowing costs (diffebitda, diffequity, diffbcosts) is correlated with the likelihood of failure, indicating first support for hypothesis (H4).

Table 5 reports the stepwise probit regression results for the likelihood of failure and identifies that overconfidence in the estimation of equity (variable diffequity) and 
EBITDA (variable diffebitda) is associated with the decision of a firm to file for financial distress. Each regression in Table 5 includes an estimation that uses only one determinant of overconfidence at a time, due to the high multicollinearity between the overconfidence measures (see Table 3). The effect that marginal variations in overconfidence have on the probability of default is equal to 0.87 for differences in equity and to 0.58 for differences in EBITDA. Interestingly, the entrepreneur's level of education (highedu) and the company's age (firmage) significantly reduce the likelihood of default. No association is found for borrowing costs (diffbcosts).

\section{[TABLE 5 ABOUT HERE]}

\section{Robustness checks}

In order to rule out the possibility that overconfidence and failure are conditioned by previous firm conditions, we replicated the step-wise regression approach followed to obtain the estimates in Table 4 by including the values of EBITDA in 2011 and 2012 (alternatively) as additional regressors. EBITDA showed a similar pattern in 2011 and 2012 , ranging from a minimum of $-140,000$ euros to a maximum of 870,000 euros, with a standard deviation of 162,798 euros in 2011 and from -221,000 euros to 919,000 euros with a standard deviation of 162,354 euros in 2012. All estimates remained virtually unchanged and, quite interestingly, EBITDA in both years does not significantly 
influence overconfidence or the likelihood of failure, meaning that the model does well in isolating the effect that personal and firm characteristics exert on the entrepreneurial propensity to overestimate performance.

Although information on the homogeneity and the dimension of the entrepreneurial team was not available, we further explored the role of a team compared to that of sole entrepreneurs by controlling the estimates for the single entrepreneur's or the entrepreneurial team's tenure, i.e. for the time they have continuously been leading the firm. It is worth noting that tenure captures a different characteristic than firmage. Variable firmage is defined as the number of years elapsed since the year of the company's incorporation, tenure is the number of years the entrepreneur or the entrepreneurial team have been in charge as of the end of 2012 and better captures managerial ability. On average, single entrepreneurs have been running the firm for 9.6 years while teams for 12.2 years: none of the two variables significantly influence the entrepreneurial overconfidence and the likelihood of failure ${ }^{3}$.

\section{Discussion}

Our results add to the emerging debate related to the hubris model of entrepreneurship. While previous literature has suggested that entrepreneurs are inclined to make

\footnotetext{
${ }^{3}$ The significance of all other regressors is also unchanged after the inclusion of entrepreneurial and team tenure, with one exception: the parameter of entralone turns out to be insignificant also in the estimate of diffbcosts and not only for diffebitda and diffbcosts. Instead, when including EBITDA from previous years, no significant effect on the other regressors emerges. Estimates are available upon request.
} 
overconfident forecasts that stem from cognitive bias and the use of heuristic methods, there is limited information on the propensity for entrepreneurs to act in an overconfident manner or the characteristics that influence such behaviour.

The empirical analysis, in contrast to previous work, relies upon the budget forecasts and actual results provided by accountants rather than information generated from selfreported attitudinal surveys (Busenitz and Barney 1997; Trevelyan 2008). This enables us to adopt a novel measure for overconfidence, computed as the variance between actual and estimated values for three economic indicators (EBITDA, equity and borrowing costs) and provides an opportunity to investigate the impact of overconfidence upon entrepreneurial behaviour and the determinants and consequences of such conduct.

The results indicate that overconfidence is a significant entrepreneurial trait exhibited by $85 \%$ of the sample and our findings also show a clear association between overconfidence and failure. Entrepreneurs that overestimate EBITDA and equity in their budgetary forecasts are more likely to file for financial distress. Importantly, the findings also support previous research (Gibson and Casser 2002; Kropp, Lindsay and Shoham 2008) that highlights the importance of education in reducing the propensity for overoptimistic forecasts and in improving a firm's chances of survival. 
Analysing the results in more detail, we first investigated the impact that entrepreneurial characteristics, namely age, gender and education, have upon the formulation of forecasts. As Forbes (2005) suggests, older entrepreneurs should, on average, have experienced more occasions in which the inaccuracy of their own knowledge has become apparent and, guided by past experience, should reduce their tendency to be overconfident in their estimates. Our findings provide little evidence to support this assertion, with age (agedm) offering no relationship with overconfident forecasts for EBITDA, equity or borrowing costs. To explore this issue further, a second variable was employed that divided the sample between those entrepreneurs who are thirty-five or under and those over thirty-five (young). This second variable provides evidence to suggest that younger entrepreneurs $(<35)$ are more likely to overestimate equity (approximately by 0.3 percent) but no significant differences were found for EBITDA or borrowing costs, thus providing limited support for the stated hypothesis (H1a). A factor pertinent to this debate is the degree to which age is a proxy for relevant experience. Ucbasaran et al. (2010) conclude that "entrepreneurial experience offers opportunities to reduce the likelihood of subsequently reported comparative optimism but this depends on the nature of the experience" (p. 552). It is possible that older entrepreneurs have not lived through the appropriate experiences and that hubris, in the form of hope for the future, is stronger than any learning that has been derived from past 
activity. This finding lends support to the arguments presented by Trevelyan (2008) that suggests that overconfidence can adversely affect firms throughout its development and that age itself is not sufficient to explain experience. More nuanced information about the entrepreneur's past experience would be needed to fully explore this relationship.

With reference to gender, the hypothesis $(\mathrm{H} 1 \mathrm{~b})$ is strongly supported with the evidence indicating that women tend to be more accurate than men in predicting the budget values of EBITDA, equity and borrowing costs. Even if few entrepreneurs in this sample are women (62 out of 203), this effect is consistent across all specifications and it is more pronounced when the dependent variable is the percentage variance in equity, where the marginal impact is approximately 3.5 percent. These results confirm previous findings and suggest that women provide more reliable estimates of future financial positions for firms they control (Barber and Odean 2001; Yardanova and Boshnakova 2011).

However performance is measured, previous research points to a positive and significant relationship between the level of general education and entrepreneurial performance (Acs, Arenius, Hay and Minniti, 2004; van der Sluis and van Prag, 2004). A possible factor underpinning this relationship concerns the role that education performs in building entrepreneurial confidence to develop skills (Koellinger, Minniti, 
and Schade 2007). While this might suggest that education levels are positively associated with overconfident forecasts, previous research (Lichtenstein and Fischoff 1977) has found that education mitigates such behaviour, making people more aware of judgmental heuristics and bias in their decision-making. The influence that education has upon the creation of overconfident estimates is therefore ambiguous. Our results suggest that a high level of education increases an entrepreneur's ability to more accurately forecast the future EBITDA, equity and borrowing costs of the firm. Hypothesis (H1c) is therefore supported. Taking into account the positive correlation between education and the use of an accounting or budgetary control system (sys), we suggest that education enables an entrepreneur to reflect on the limits associated with heuristic methods and have the confidence/capability to employ more sophisticated forecasting techniques, also found to mitigate against overconfidence.

In the general business literature (Collins and Clark 2003; Helfat 2015), there is interest in understanding and linking specific team attributes to firm performance. Although not as well established, a similar stream has emerged in the entrepreneurship literature (Ensley, Pearson, Amason and Allen, 2002; Lubatkin, Simsek, Ling and Veiga, 2006). Critical to such arguments is the premise that the management of entrepreneurial ventures is often a shared effort (Page-West 2007). Our dataset can be divided into firms where entrepreneurs identified themselves as solely responsible for financial 
forecasts and firms where such responsibility was coordinated between an entrepreneurial team. The results indicate that individual entrepreneurs are more likely to overestimate forecasts for borrowing costs but no significant differences are found in the accuracy of EBITDA or equity predictions. Differentials in borrowing costs may be derived from unexpected changes in the market conditions for existing debt contracts, or from cash flow problems that require new financing arrangements or further overdraft facilities. As a consequence, hypothesis (H2) is only partially supported. It may well be the case that hubris is as much a feature of entrepreneurial teams as it is with individual entrepreneurs; as Page-West (2007) acknowledges, teams are not removed from the problems faced by small firms so "one would expect teams, like individuals, to rely on mental models or schema as a heuristic aid to interpretation and decision making" (p. $80)$.

Previous literature has identified the disadvantages of using heuristic methods upon which to base future estimations (Baron 2004; Mitchell et al. 2002) and encourages entrepreneurs towards more formal systems that are expected to limit bias and overconfidence. It is recognised that SMEs are less likely to use such methods (ACCA 2010; Collins and Jarvis 2002) and this is reflected in our sample with only 49 firms out of 203 making use of an accounting or budgetary control system. Our results indicate that the presence of such a system is highly influential in accurately predicting EBITDA 
and is also significant in minimizing the difference between planned and actual for both borrowing costs and equity. Therefore, when internal planning is managed using an accounting or budgetary control system, forecasts are more accurate than when the estimation process relies on heuristic methods, thus confirming Hypothesis (H3).

The final hypothesis investigated associations between overconfidence and business failure. Our results support Hypothesis (H4) and indicate that overconfidence in the forecasting of EBITDA and equity are strongly associated with the failure of a firm. These findings provide empirical evidence to underpin assertions in the extant literature that have indicated the probability of such a relationship (De Meza and Southey 1996; Koellinger, Minniti, and Schade 2007). It should be noted that our sample does not include very early stage firms, which may be at greatest risk from the "liability of adolescence" (Bruderl and Schussler 1990; Fichman and Levinthal 1991). This is relevant as the variable firmage, not identified as a factor influencing overconfidence, is instead an important condition that protect against failure. Therefore, the inclusion of firms that are less than two years old is likely to strengthen the existing relationship linking overconfident forecasts with firm failure. Overconfidence, however, can be mitigated by education and the deployment of accounting or budgetary control systems. We would propose that education helps to raise entrepreneurial awareness of the limitations of heuristics and encourages the effective utilisation of accounting or 
budgetary control systems curbing the natural hubris of the entrepreneur. Education and accounting or budgetary control systems therefore limit the propensity of a firm to file for financial distress.

\section{Conclusions}

A hubris theory of entrepreneurship models how overconfidence can influence the decision to start a firm and its performance once established. For early-stage entrepreneurs, overconfidence could be beneficial and provide them with the energy and enthusiasm to pursue opportunities in difficult contexts (Koellinger, Minniti and Schade, 2007; Robinson and Marino 2015). However, once firms are well established, overconfidence has the potential to adversely affect firm performance, as entrepreneurs pursue challenging goals with limited resource (Hayward, Shepherd and Griffin 2006). As a consequence, hubris theory concludes that such overconfidence embedded in an entrepreneur's psychology increases the likelihood of failure among entrepreneurial firms (De Meza and Southey 1996; Koellinger, Minniti and Schade 2007). While hubris theory is well documented in the literature, our understanding of why entrepreneurs exhibit more overconfidence than non-entrepreneurs is a moot point. This article has addressed the suggestion that the entrepreneurial context appeals to individuals that are inclined to employ heuristics in their decision-making and that such attitudes lead to the formulation of overconfident forecasts. While there is limited information on the 
propensity for entrepreneurs to act in an overconfident manner, our findings identify that approximately $85 \%$ of entrepreneurs sampled provided financial estimates that were better than those actually attained. Hubris is therefore embedded in the overwhelming majority of the sample population. More so, it is embedded in entrepreneurial firms that are more than two years old and, on average, have been in business for sixteen years; this suggests that such attitudes hold over time. The predisposition for entrepreneurs to be overconfident is only an issue if, as previously asserted by many researcher (De Meza and Southey 1996; Hayward, Shepherd and Griffin 2006; Koellinger, Minniti, and Schade 2007), it has a negative impact upon performance. Our evidence provides empirical support for these assertions and shows that overconfidence in the forecasts of EBITDA and equity are strongly associated with an entrepreneur's decision to file for financial distress. It is possible to decrease entrepreneurial overconfidence by increasing the levels of educational attainment achieved by entrepreneurs and through the use of accounting or budgetary control systems. While it is virtually impossible to control for all the determinants of failure, our findings point to education helping entrepreneurs to understand the limitations of heuristic methods and providing the confidence and competence to effectively use accounting or budgetary control systems. The findings also indicate that overconfidence is less prevalent among women business owners. 
Our study has some limitations that give rise to opportunities for further research. First, this is a highly contextualised study using evidence drawn from Piedmont in Northern Italy with the support of three accounting firms that collect their data. While the independent variables do confer confidence in the findings, it would be appropriate to extend the research to firms that do not use accounting firms and broaden the geographical reach of the study. However, the positive impact of accounting or budgeting systems in reducing forecasting biases in small companies seems likely to transfer across countries where the adoption of such systems is heterogeneous and generally poor (Levy et al. 2001; Cassar and Gibson 2007; Hmieleski and Baron 2009; Ismail and King 2014). Secondly, future research might include cognitive trait scales to validate the conceptual assumption of the linkage between overconfident entrepreneurs and entrepreneurs who set overconfident forecasts. Thirdly, our sample does not include firms recently established and it is possible that this is a sub-sector of the small and micro firms segment in which firms that are most susceptible to hubris and perhaps least equipped to survive any negative impacts that result from such attitudes. Incorporating very early stage firms may provide greater evidence of the relationship between overconfidence and business failure. Finally, a sensitivity analysis that goes beyond the main trends might unclose punctual overconfidence thresholds where overconfidence is ruinous. A possible approach to test for this effect would be the floodlight analysis (Spiller, Fitzsimons, Lynch and McClelland 2013). 


\section{References}

ACCA and CBI (2010), 'Small business finance and the recovery: Results of the 2010 SME credit and finance surveys', Accountancy Futures

Acs, Z.J., Arenius, P., Hay, M. and Minniti, M. (2004), Global Entrepreneurship Monitor: Executive Report, Babson College, Babson, MA

Alvarez, S and Busenitz, L. (2001), 'The entrepreneurship of resource-based theory', Journal of Management, Vol. 27, pp. 755-776

Barber, B., and Odean, T. (2001), 'Boys will be boys: gender, overconfidence and common stock investment', Quarterly Journal of Economics 116 (1), pp. 261-292

Baron, R. (1998), 'Cognitive mechanisms in entrepreneurship: why and when entrepreneurs think differently than other people', Journal of Business Venturing, Vol. 13, pp. 275-294

Baron, R. (2004), 'The cognitive perspective: a valuable tool for answering entrepreneurship's basic “why” questions', Journal of Business Venturing 19, pp. 221239

Bartoli, F., Ferri, G., Murro, P., and Rotondi, Z. (2014), 'Bank support and export: evidence from small Italian firms', Small Business Economics, Vol. 42 No. 2, pp. 245264

Beyer, S., and Bowden, E.M. (1997), 'Gender differences in self-perceptions: convergent evidence from three measures of accuracy and bias', Personality and Social Psychology Bulletin, Vol. 23, pp. 157-172

Bonte, W., and Piegeler, M. (2013), 'Gender gap in latent and nascent entrepreneurship: driven by competitiveness', Small Business Economics, Vol. 41 No. 4, pp. 961-987

Bruderl, J., and Schussler, R. (1990), 'Organizational Mortality: The Liabilities of Newness and Adolescence', Administrative Science Quarterly, 35 pp. 530-547

Busenitz, L., and Barney, J. (1994), 'Biases and heuristics in strategic decision making: differences between entrepreneurs and managers in large organizations', Academy of Management Best Papers Proceedings, pp. 85-89

Busenitz, L., and Barney, J. (1997), 'Differences between entrepreneurs and managers in large organizations: Biases and heuristics in strategic decision-making', Journal of Business Venturing, Vol. 12, pp. 9-30 
Carter, R., and Van Auken, H. (2006), 'Small Firm Bankruptcy', Journal of Small Business Management, Vol. 44(4), pp. 493-512

Carter, S., Mwaura, S., Ram, M., and Jones, T., '(2015) Barriers to ethnic minority and women's enterprise: Existing evidence, policy tensions and unsettled questions, International Small Business Journal, Vol. 33(1) 49-69

Cassar, G., and Gibson, B. (2007), 'Forecast Rationality in Small Firms', Journal of Small Business Management, Vol. 45 No. 3, pp. 283-302

Chapman, C. S. (1997), 'Reflections on a Contingent View of Accounting', Accounting Organisations and Society, Vol. 22, pp. 189 - 205

Cheung, S., and Palan, S. (2012), 'Two heads are less bubbly than one: team decisionmaking in an experimental asset market', Experimental Economics, Vol. 15 No. 3, pp. 373-397

Ciambotti, M., Aureli, S., Giampaoli, D. (2012). 'I sistemi informativi automatizzati a supporto dei processi di direzione aziendale. Ancora un ritardo cronico per le piccole imprese?', Controllo di gestione 6/2012, pp. 48-59

Ciampi, F., and Gordini, N. (2009), 'Default prediction modeling for small enterprises: Evidence from small manufacturing firms in northern and central Italy', Oxford Journal, Vol. 8 No. 1, pp. 13-29.

Ciampi, F., and Gordini, N. (2013), 'Small enterprise default prediction modelling through artificial neural networks: An empirical analysis of Italian small enterprises', Journal of Small Business Management, Vol. 51 No. 1, pp. 23-45

Coad, A., Segarra, A., and Teruel, M. (2013), 'Like milk or wine: Does firm performance improve with age?', Structural Change and Economic Dynamics, Vol. 24, pp. $173-189$

Coleman, S. (2000). Access to capital and terms of credit: A comparison of men- and women-owned small businesses. Journal of Small Business Management, 38(3), 37-52.

Collins, C., and Clark, K. (2003), 'Strategic Human Resource Practices, Top Management Team Social Networks, and Firm Performance: The Role of Human Resource Practices in Creating Organizational Competitive Advantage', Academy of Management Journal Vol. 46 No. 6, pp. 740-751

Collis, J. and Jarvis, R. (2002), 'Financial information and the management of small private companies', Journal of Small Business and Enterprise Development, Vol. 9 Issue 2 pp. 100 - 110 
Colombo, M.G. and Grilli, L. (2005), 'Founders' human capital and the growth of new technology-based firms: A competence-based view', Research Policy, 34(6), pp. 795818

Cooper, A.C., Woo, C., Dunkelberg, W. (1988), 'Entrepreneurs' perceived chances of success', Journal of Business Venturing 3, pp. 97-108

Dawson, C., and Henley, A. (2012), 'Over-optimism and entry and exit from selfemployment', International Small Business Journal, Vol. 31 No. 8, pp. 938-954

De Jorge Moreno, J., Castillo, L. L., and Masere, E. D. Z. (2007), 'Influence of entrepreneur type, region and sector effects on business self-confidence: Empirical evidence from Argentine firms', Entrepreneurship and Regional Development, Vol. 19 No. 1, pp. 25-48

De Meza, D., and Southey, C. (1996), 'The borrower's curse: optimism, finance and entrepreneurship', Economic Journal, Vol. 106, No 435, pp. 375-386

Diamantopoulos, A., and Winklhofer, H. (1999), 'The impact of firm and export characteristics on the accuracy of export sales forecast: Evidence from UK Exporters', International Journal of Forecasting, Vol. 15, pp. 67-81

Digital4Executives (2013), 'Politecnico di Milano: I gestionali diffusi nel 91\% delle PMI italiane. In crescita gli ERP complessi, ancora marginale l'as-a-service', Retrieved July 15, 2016, from https://www.digital4.biz/executive/approfondimenti/ricerca-del-politecnico-di-milano-igestionali-diffusi-nel-91-delle-pmi-italiane-in-crescita_4367215273.htm

Dunne, T., M. J. Roberts and L. Samuelson (1988), 'Patterns of firm entry and exit in U.S. manufacturing industries', RAND Journal of Economics, Vol. 19, pp. 495-515

Ensley, M., Pearson, A., Amason, A., and Allen C. (2002), 'Understanding the dynamics of new venture top management teams: Cohesion, conflict, and new venture performance', Journal of Business Venturing 17, pp. 365-386

European Commission (2014), 'Enterprise and Industry Italy' SBA Fact Sheet

Evans, D. S. (1987), 'The relationship between firm growth, size and age: Estimation for 100 manufacturing industries', Journal of Industrial Economics, Vol. 35, pp. $567-581$

Fichman, M., Levinthal, D. A. (1991), 'Honeymoons and the Liability of Adolescence: A New Perspective on Duration Dependence in Social and Organizational Relationships' Academy of Management Review April 1, 1991 Vol. 16 No. 2, pp. 442-468 
Forbes, D.P. (2005), 'Are some entrepreneurs more overconfident than others?', Journal of Business Venturing, Vol. 20, pp. 623-640

Freel, M., Carter, S., Tagg, S., and Mason, C., (2012) The latent demand for bank debt: characterizing “discouraged borrowers, Small Business Economics Vol. 8 No. 4

Gibson, B., and Cassar, G. (2002), 'Planning behaviour variables in small firms', Journal of Small Business Management, Vol. 40 No. 3, pp. 171-186

Grandi, A. and Grimaldi, R. (2003), 'Exploring the networking characteristics of new venture founding teams', Small Business Economics, 21(4), pp. 329-347

Hayward M.L.A., Forster W. R., Sarasvathy, S., D., and Fredrickson, B., L. (2010), 'Beyond hubris: How highly confident entrepreneurs rebound to venture again', Journal of Business Venturing vol. 25, pp. 569-578

Hayward, M.L.A., Shepherd, D.A., Griffin, D. (2006), 'A hubris theory of entrepreneurship', Management Science, Vol. 52, pp. 160-172

Helfat, C. (2015), 'Dynamic Managerial Capabilities Review and Assessment of Managerial Impact on Strategic Change', Journal of Management Vol. 41 No. 5, pp. $1281-1312$

Hmieleski, K.M., and Baron, R.A. (2009), 'Entrepreneurs' optimism and new venture performance: a social cognitive perspective', Academy of Management Journal, Vol. 52, pp. $473-488$

Houghton, S. M., Simon, M., Aquino, K., and Goldberg, C. (2000), 'No safety in numbers: Persistence of biases and their effects on team perception and team decision making', Group and Organization Management, Vol. 25, No. 4, pp. 325-353

Huang, and Kisgen, D.J. (2013), 'Gender and corporate finance: Are male executives overconfident relative to female executives?', Journal of Financial Economics, Vol. 108 No. 3, pp. 822-839

Ismail, N. A., and King, M. (2014), 'Factors influencing the alignment of accounting information systems in small and medium sized Malaysian manufacturing firms', Journal of Information Systems and Small Business, Vol. 1 No. 1-2, pp. 1-20

ISTAT (2013), Piemonte in cifre, Annuario Statistico Regionale, available at: http://www.piemonteincifre.it/indexnews.php

Jenkins, A. and McKelvie, A. (2016), 'What is entrepreneurial failure? Implications for future research', International Small Business Journal, Vol. 34(2), pp.176 - 188 
Jovanovic, B. (1982), 'Selection and the evolution of industry', Econometrica 50(3), pp. 649-670

Koellinger, P., Minniti, M. and Schade, C. (2007), 'I think I can, I think I can': overconfidence and entrepreneurial behaviour', Journal of Economic Psychology, Vol. 28 No. 4 , pp. $502-27$

Kropp, F., Lindsay, N.J. and Shoham, A. (2008), 'Entrepreneurial orientation and international entrepreneurial business venture startup', International Journal of Entrepreneurial Behaviour and Research, Vol. 14 No. 2, pp. 102-117

Kugler, T., Kausel, E.E. and Kocher, M.G. (2012), 'Are groups more rational than individuals? A review of interactive decision making in groups', Wiley Interdisciplinary Reviews: Cognitive Science, Vol. 3 No. 4, pp. 471-482

Landier, A and Thesmar, D., ( 2009) 'Financial Contracting with Optimistic Entrepreneurs', The Review of Financial Studies, Vol. 22, No. 1, pp. 117-150, 2009

Levesque, M. and Minniti, M. (2006), 'The effect of aging on entrepreneurial behaviour', Journal of Business Venturing, Vol. 21 No. 2, pp. 177-194

Levy, M., Powell, P. and Yetton, P. (2001), 'SMEs: aligning IS and the strategic context', Journal of Information technology, Vol. 16 No. 3, pp. 133-144

Lichtenstein, S., \& Fischhoff, B. (1977). 'Do those who know more also know more about how much they know?' Organizational Behaviour and Human Performance Vol. 20 pp. $159-183$.

Liedholm, C.E. and Mead, D.C. (2013), Small enterprises and economic development: the dynamics of micro and small enterprises. Routledge

Lovallo, D. and Kahneman, D. (2003), 'Delusions of Success: How Optimism Undermines Executives' Decisions', Harvard Business Review, Vol. 81 No. 7, pp. 5663

Lubatkin, M., Simsek, Z., Ling, Y. and Veiga, J. (2006), 'Ambidexterity and Performance in Small-to Medium-Sized Firms: The Pivotal Role of Top Management Team Behavioural Integration', Journal of Management Vol. 32 No.5, pp. 646-672

Markovitch, D.G., Steckel, J.H., Michaut, A., Philip, D. and Tracy, W.M. (2015), 'Behavioral Reasons for New Product Failure: Does Overconfidence Induce Overforecasts?', Journal of Product Innovation Management, Vol. 32, No. 5, pp. 825841 
Marlow, S.; Swail, J.(2014)., "Gender, Risk and Finance why can't a woman be more", Entrepreneurship and Regional Development, Vol.26 (1-2), pp. 80-96.

Mitchell, R.K., Busenitz, L., Lant, T., McDougall, P.P., Morse, E.A., Brock Smith, J. (2002), 'Toward a theory of entrepreneurial cognition: rethinking the people side of entrepreneurship research', Entrepreneurship Theory and Practice, Vol. 27, pp. 93-104

Morrell, M. and Ezingeard, J.N. (2002), 'Revisiting adoption factors of interorganisational information systems in SMEs', Logistics Information Management, Vol. 15 No. 1 , pp. 46-57

Neergaard, H. (2005), 'Networking activities in technology-based entrepreneurial teams', International Small Business Journal, 23(3), pp. 257-274

Page-West, G. (2007) 'Collective Cognition: When Entrepreneurial Teams, Not Individuals, Make Decisions', Entrepreneurship Theory and Practice Vol. 31, Issue 1, pp. $77-102$

Robinson, A.T. and Marino, L.D. (2015), 'Overconfidence and risk perceptions: do they really matter for venture creation decisions?', International Entrepreneurship and Management Journal, Vol. 11 No. 1, pp. 149-168

Ruef, M., Aldrich, H.E. and Carter, N.M. (2003), 'The structure of founding teams: Homophily, strong ties, and isolation among U.S. entrepreneurs', American Sociological Review, 68(2), pp. 195-222

Santoni, S., Fini, R., Grimaldi, R. and Wright, M. (2013). 'How Does Team Diversity Evolve? Exploring Alternative Perspectives on Entrepreneurial Team Change' Academy of Management Proceedings, Vol. 2013, No. 1, pp. 16240

Saridakis, G., Mole, K. and Storey, D. J. (2008) 'New small firm survival in England', Empirica Vol. 35: No 1 pp. 25-39

Sautner, Z. and Weber, M. (2009), 'How do Managers Behave in Stock Option Plans? Clinical Evidence from Exercise and Survey Data', Journal of Financial Research, Vol. 32 No. 2, pp. 123-155

Shepherd, D.A., Wiklund, J. and Haynie, J.M. (2009). 'Moving forward: Balancing the financial and emotional costs of business failure', Journal of Business Venturing, Vol. 24, pp. 134-148

Short, J.C., McKelvie, A., Ketchen, D.J. and Chandler, G.N. (2009), 'Firm and industry effects on firm performance: A generalization and extension for new ventures', Strategic Entrepreneurship Journal, Vol. 3 No. 1, pp. 47-65 
Smith, H.C.III., Herbig, P., Milewicz, J. and Golden, J.E. (1996), 'Differences in Forecasting Behaviour between Large and Small Firms', Journal of Marketing Practice: Applied Marketing Science, Vol. 2 No. 1, pp. 35-51

Spiller, S.A., Fitzsimons, G.J, Lynch, J.G., and McClelland, G.H. (2013) 'Spotlights, Floodlights, and the Magic Number Zero: Simple Effects Tests in Moderated Regression', Journal of Marketing Research Vol. 50, No. 2, pp. 277-288

Tipu, S.A.A. and Arain, F. M. (2011). 'Managing success factors in entrepreneurial ventures: a behavioral approach', International Journal of Entrepreneurial Behaviour and Research, Vol. 17 No. 5, pp. 534-560

Treichel, M and Scott, J. (2006) Women-Owned businesses and access to bank credit: Evidence from three surveys since 1987, Venture Capital, 8, pp. 51-67

Trevelyan, R. (2008), 'Optimism, overconfidence and entrepreneurial activity', Management decision, Vol. 46 No. 7, pp. 986-1001

Ucbasaran, D., Westhead, P., Wright, M. and Flores, M. (2010) 'The nature of entrepreneurial experience, business failure and comparative optimism', Journal of Business Venturing Vol. 25, pp 541-555

van der Sluis, J., van Praag, M. (2008), 'Education And Entrepreneurship' Selection and Performance: A Review of the Empirical Literature', Journal of Economic Surveys Vol. 22, No. 5, pp. 795-841

Wennberg K and DeTienne D. (2014) 'What do we really mean when we talk about 'exit'? A critical review of research on entrepreneurial exit', International Small Business Journal, Vol. 32(1), pp. 4-16

Yaniv, I. (2011), 'Group diversity and decision quality: amplification and attenuation of the framing effect', International Journal of Forecasting, Vol. 27 No. 1, pp. 41-49

Yardanova, D.I. and Boshnakova, M.I.A. (2011), 'Gender effects on risk-taking of entrepreneurs: evidence from Bulgaria', International Journal of Entrepreneurial Behaviour and Research, Vol. 17 No. 3, pp. 272-295 
Figure 1. Average percentage differences between the budget values and actual balance sheet values for the variables: EBITDA, equity and borrowing costs

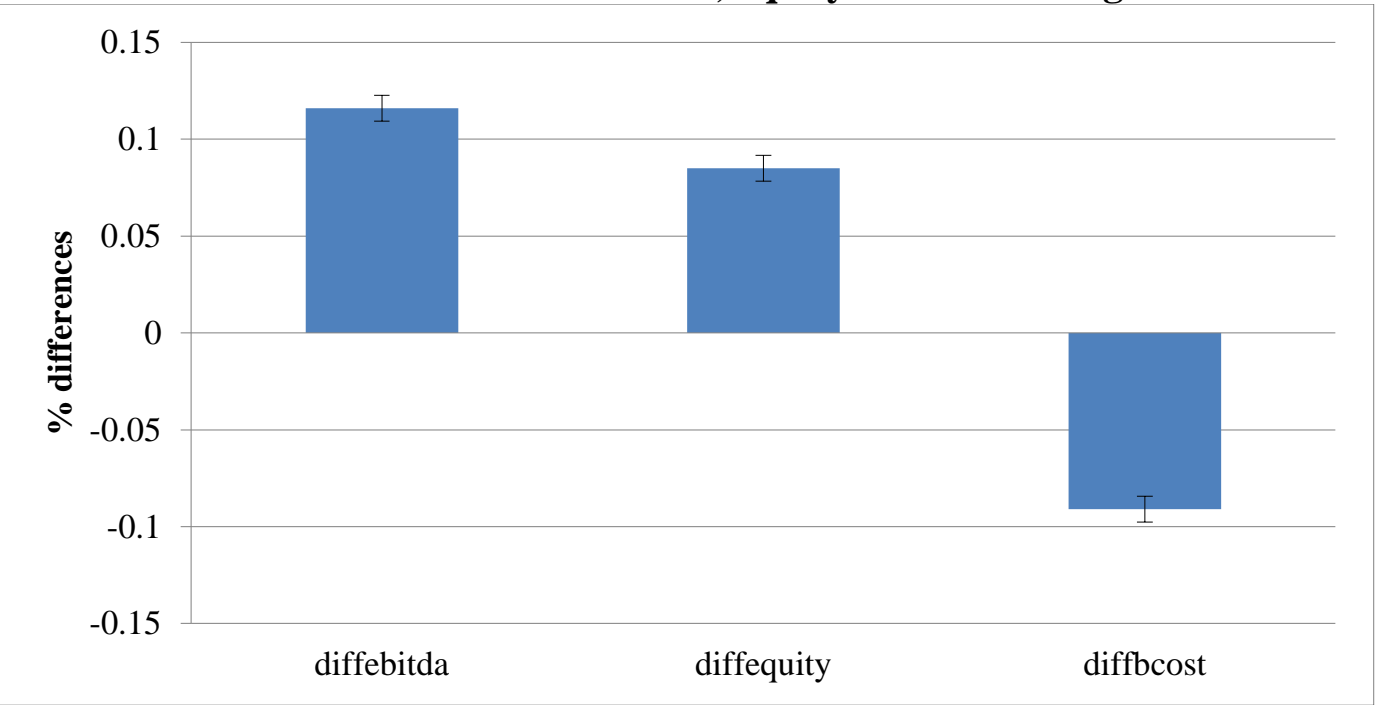

Average percentage differences between budget values and actual balance sheet values: diffebitda is the percentage difference between forecasted and actual EBITDA, diffbcosts is the percentage difference between forecasted and actual borrowing costs, diffequity is the percentage difference between forecasted and actual equity. The percentage differences are computed as per Equation [1]. Number of firms: 203. 
Table 1: A Comparison of Industry Structure - Italy and the EU

\begin{tabular}{|l|l|l|l|l|l|l|}
\hline & \multicolumn{2}{l|}{$\begin{array}{l}\text { Number of } \\
\text { Enterprises (\%) }\end{array}$} & \multicolumn{2}{l|}{$\begin{array}{l}\text { Number of } \\
\text { Employees (\%) }\end{array}$} & \multicolumn{2}{l|}{ Value Added (\%) } \\
\hline $\begin{array}{l}\text { Firm } \\
\text { dimension }\end{array}$ & Italy & EU & Italy & EU & Italy & EU \\
\hline Micro & 94.8 & 92.4 & 45.8 & 29.1 & 30.4 & 21.6 \\
\hline Small & 4.6 & 6.4 & 21.1 & 20.6 & 21.3 & 18.2 \\
\hline Medium & 0.5 & 1.0 & 12.7 & 17.2 & 17.8 & 18.3 \\
\hline Large & 0.1 & 0.2 & 20.4 & 33.1 & 30.5 & 41.9 \\
\hline Total & 100 & 100 & 100 & 100 & 100 & 100 \\
\hline
\end{tabular}

Adapted from the European Commission (2014) Enterprise and Industry - Italy, SBA Fact Sheet. 
Table 2: Definition of Variables $(\mathrm{N}=\mathbf{2 0 3})$

\begin{tabular}{|c|c|c|c|c|}
\hline Category & Abbreviation & Definition & Mean & St. Dev. \\
\hline \multirow{4}{*}{$\begin{array}{l}\text { Personal } \\
\text { characteristics } \\
\text { of the } \\
\text { entrepreneur }\end{array}$} & agedm & Entrepreneur's age & 45.167 & 13.013 \\
\hline & young & $\begin{array}{l}\text { Dummy variable equal to } 1 \text { if } \\
\text { the entrepreneur or the } \\
\text { entrepreneur is younger than } \\
35,0 \text { otherwise }\end{array}$ & 0.236 & 0.425 \\
\hline & gender & $\begin{array}{l}\text { Dummy variable equal to } 1 \text { if } \\
\text { the entrepreneur is a women } \\
\text { and } 0 \text { otherwise }\end{array}$ & 0.305 & 0.461 \\
\hline & highedu & $\begin{array}{l}\text { Dummy variable equal to } 1 \text { if } \\
\text { the entrepreneur holds a degree } \\
\text { (undergraduate or higher), } 0 \\
\text { otherwise }\end{array}$ & 0.300 & 0.460 \\
\hline \multirow[t]{8}{*}{$\begin{array}{l}\text { Firm } \\
\text { characteristics }\end{array}$} & entralone & $\begin{array}{l}\text { Dummy variable equal to } 1 \text { in } \\
\text { case of single founder, } 0 \\
\text { otherwise }\end{array}$ & 0.502 & 0.501 \\
\hline & sys & $\begin{array}{l}\text { Dummy variable equal to } 1 \text { if } \\
\text { there is an integrated } \\
\text { accounting or budgetary } \\
\text { control system, } 0 \text { otherwise }\end{array}$ & 0.241 & 0.429 \\
\hline & failure & $\begin{array}{l}\text { Dummy variable equal to } 1 \text { if } \\
\text { the firm have ceased the } \\
\text { activity for financial distress up } \\
\text { to April } 2014,0 \text { otherwise }\end{array}$ & 0.172 & 0.379 \\
\hline & manufacturing & $\begin{array}{l}\text { Dummy variable equal to } 1 \text { if } \\
\text { the firm is in the mechanical } \\
\text { industry, } 0 \text { otherwise }\end{array}$ & 0.295 & 0.457 \\
\hline & commerce & $\begin{array}{l}\text { Dummy variable equal to } 1 \text { if } \\
\text { the firm is in the commercial } \\
\text { industry, } 0 \text { otherwise }\end{array}$ & 0.295 & 0.457 \\
\hline & services & $\begin{array}{l}\text { Dummy variable equal to } 1 \text { if } \\
\text { the firm is in the services } \\
\text { industry, } 0 \text { otherwise }\end{array}$ & 0.408 & 0.492 \\
\hline & size & Number of employees & 6.374 & 5.059 \\
\hline & firmage & $\begin{array}{l}\text { Number of years since the } \\
\text { firm's constitution }\end{array}$ & 16.320 & 10.461 \\
\hline \multirow[t]{3}{*}{$\begin{array}{l}\text { Entrepreneurial } \\
\text { overconfidence }\end{array}$} & diffebitda & $\begin{array}{l}\text { Percentage difference between } \\
\text { actual and forecasted EBITDA }\end{array}$ & 0.116 & 0.091 \\
\hline & diffequity & $\begin{array}{l}\text { Percentage difference between } \\
\text { actual and forecasted equity }\end{array}$ & 0.085 & 0.076 \\
\hline & diffbcosts & $\begin{array}{l}\text { Percentage difference between } \\
\text { actual and forecasted } \\
\text { borrowing costs }\end{array}$ & 0.091 & 0.080 \\
\hline
\end{tabular}


Table 3: Pearson correlation

\begin{tabular}{|c|c|c|c|c|c|c|c|c|c|c|c|c|c|c|c|}
\hline & agedm & young & gender & highedu & entralone & sys & failure & manuf. & comm. & services & size & firmage & diffebitda & $\begin{array}{l}\text { diffequit } \\
y\end{array}$ & $\begin{array}{l}\text { diffb } \\
\text { costs } \\
\end{array}$ \\
\hline agedm & 1 & & & & & & & & & & & & & & \\
\hline young & $-0.11^{* * * *}$ & 1 & & & & & & & & & & & & & \\
\hline gender & 0.031 & -0.04 & 1 & & & & & & & & & & & & \\
\hline highedu & $-0.19^{* * *}$ & $\begin{array}{ll}0.09 \\
\end{array}$ & $0.20^{* *}$ & $\begin{array}{ll}1 \\
\end{array}$ & & & & & & & & & & & \\
\hline entralone & $-0.23 * * *$ & $0.25 * * *$ & $-0.15^{* *}$ & $-0.23^{* * * *}$ & 1 & & & & & & & & & & \\
\hline sys & -0.04 & 0.01 & -0.07 & $0.16^{* * *}$ & $\begin{array}{l}-0.06 \\
-0.0\end{array}$ & 1 & & & & & & & & & \\
\hline failure & $-0.19 * * *$ & 0.053 & 0.01 & 0.07 & $0.14^{* *}$ & -0.07 & 1 & & & & & & & & \\
\hline manuf. & $0.20^{* * * *}$ & $\begin{array}{l}-0.13^{*} \\
\end{array}$ & $-0.154^{* * *}$ & $\begin{array}{l}-0.07 \\
\end{array}$ & $\begin{array}{l}-0.01 \\
\end{array}$ & $-0.14 * *$ & $\begin{array}{l}-0.12^{*} \\
\end{array}$ & 1 & & & & & & & \\
\hline comm. & 0.03 & $\begin{array}{l}-0.08 \\
\end{array}$ & 0.06 & $0.16^{* * *}$ & -0.07 & $0.19^{* * * *}$ & -0.01 & $-0.42^{* * * *}$ & 1 & & & & & & \\
\hline services & $-0.22 * * *$ & $0.20^{\text {***** }}$ & 0.08 & $\begin{array}{l}-0.09 \\
\end{array}$ & 0.07 & $\begin{array}{l}-0.05 \\
\end{array}$ & $0.12^{*}$ & $-0.54 * * *$ & $-0.54^{* * * *}$ & 1 & & & & & \\
\hline size & $0.15^{* * *}$ & $-0.19 * * *$ & -0.02 & 0.05 & $-0.35^{* * * *}$ & 0.04 & $\begin{array}{c}-0.10 \\
\end{array}$ & $\begin{array}{l}0.03 \\
\end{array}$ & 0.04 & -0.06 & 1 & & & & \\
\hline firmage & $0.35 * * *$ & $-0.27 * * *$ & $\begin{array}{ll}0.01 \\
\end{array}$ & $\begin{array}{ll}0.02 \\
\end{array}$ & $-0.26^{* * *}$ & $\begin{array}{ll}0.14^{* *} \\
\end{array}$ & $-0.21 * * *$ & $\begin{array}{l}0.15^{* * *} \\
\end{array}$ & 0.04 & $-0.17^{* * *}$ & $0.29 * * *$ & 1 & & & \\
\hline diffebitda & 0.030 & 0.04 & $-0.19^{* * * *}$ & $-0.29^{* * * *}$ & 0.26 & $-0.24 * * *$ & $0.15^{* *}$ & 0.01 & -0.04 & 0.02 & $-0.23^{* * *}$ & $-0.19^{* * * *}$ & 1 & & \\
\hline diffequity & -0.08 & $0.19 * * *$ & $-0.24^{* * * *}$ & $-0.23^{* * *}$ & $0.27^{* * *}$ & $-0.16^{* *}$ & $0.20^{* * * *}$ & -0.01 & -0.02 & 0.02 & $-0.21^{* * *}$ & $-0.16^{*}$ & $0.86^{* * * *}$ & 1 & \\
\hline diffbcosts & 0.04 & 0.072 & $-0.22 * * *$ & $-0.27 * * *$ & $0.28^{* * * *}$ & $-0.23^{* * * *}$ & $0.12^{*}$ & -0.05 & 0.05 & 0.01 & $-0.17^{* *}$ & $-0.16 * *$ & $0.85^{* * * *}$ & $0.85^{* * *}$ & 1 \\
\hline
\end{tabular}

Pairwise Pearson correlations between variables.

*** denotes significance at 1 percent level, $* *$ at 5 percent level, $*$ at 10 percent level. 
Table 4: Overconfidence in EBITDA, Equity and Borrowing Costs

Estimation

\begin{tabular}{|c|c|c|c|c|c|c|}
\hline & (1) & (2) & (3) & (4) & (5) & (6) \\
\hline Variables & \multicolumn{2}{|c|}{ diffebitda } & \multicolumn{2}{|c|}{ diffequity } & \multicolumn{2}{|c|}{ diffbcosts } \\
\hline \multirow{2}{*}{ young } & -0.005 & & $0.026^{*}$ & $0.030 * *$ & 0.003 & \\
\hline & $(0.015)$ & & $(0.014)$ & $(0.014)$ & $(0.015)$ & \\
\hline \multirow[t]{2}{*}{ gender } & $-0.032 * * *$ & $-0.034 * * *$ & $-0.035 * * *$ & $-0.036 * * *$ & $-0.034 * * *$ & $-0.030 * * *$ \\
\hline & $(0.012)$ & $(0.012)$ & $(0.010)$ & $(0.010)$ & $(0.011)$ & $(0.010)$ \\
\hline \multirow[t]{2}{*}{ highedu } & $-0.041 * * *$ & $-0.044 * * *$ & $-0.026 * *$ & $-0.028 * * *$ & $-0.032 * * *$ & $-0.029 * * *$ \\
\hline & $(0.013)$ & $(0.012)$ & $(0.010)$ & $(0.010)$ & $(0.010)$ & $(0.010)$ \\
\hline \multirow[t]{2}{*}{ entralone } & 0.020 & & 0.016 & & $0.025 * *$ & $0.033 * * *$ \\
\hline & $(0.013)$ & & $(0.011)$ & & $(0.011)$ & $(0.010)$ \\
\hline \multirow[t]{2}{*}{ sys } & $-0.045^{* * *}$ & $-0.046 * * *$ & $-0.028 * *$ & $-0.027 * *$ & $-0.042 * * *$ & $-0.038 * * *$ \\
\hline & $(0.014)$ & $(0.014)$ & $(0.012)$ & $(0.011)$ & $(0.015)$ & $(0.011)$ \\
\hline \multirow[t]{2}{*}{ size } & $-0.002 * *$ & $-0.004 * * *$ & $-0.002 * *$ & $-0.003 * * *$ & -0.001 & \\
\hline & $(0.001)$ & $(0.001)$ & $(0.001)$ & $(0.001)$ & $(0.000)$ & \\
\hline \multirow[t]{2}{*}{ firmage } & -0.000 & & -0.000 & & -0.000 & \\
\hline & $(0.000)$ & & $(0.000)$ & & $(0.000)$ & \\
\hline \multirow[t]{2}{*}{ Constant } & $0.168 * * *$ & $0.176 * * *$ & $0.110 * * *$ & $0.121 * * *$ & $0.120 * * *$ & $0.101 * * *$ \\
\hline & $(0.019)$ & $(0.011)$ & $(0.016)$ & $(0.010)$ & $(0.017)$ & $(0.010)$ \\
\hline Sector dummies & yes & yes & yes & yes & yes & yes \\
\hline Observations & 203 & 203 & 203 & 203 & 203 & 203 \\
\hline R-squared & 0.220 & 0.199 & 0.200 & 0.185 & 0.222 & 0.187 \\
\hline
\end{tabular}

OLS estimation of the determinants of overconfidence (White's heteroskedasticity-consistent standard errors in parentheses).

$* * *$ denotes significance at 1 percent level, $* *$ at 5 percent level, $*$ at 10 percent level. 
Table 5: Overconfidence and the likelihood of failure

\begin{tabular}{|l|l|l|}
\hline & \multicolumn{1}{|c|}{$(1)$} & \multicolumn{1}{|c|}{$(2)$} \\
\hline Variables & \multicolumn{2}{|c|}{ failure } \\
\hline & \multicolumn{2}{|c|}{} \\
\hline diffebitda & $2.530^{*}$ & \\
\hline & $(1.383)$ & \\
\hline diffequity & & $3.866^{* *}$ \\
\hline & & $(1.511)$ \\
\hline firmage & $-0.036^{* * *}$ & $-0.037^{* * *}$ \\
\hline & $(0.0106)$ & $(0.0109)$ \\
\hline highedu & $-0.411^{*}$ & $-0.418^{*}$ \\
\hline & $(0.248)$ & $(0.248)$ \\
\hline Constant & $-0.880^{* * *}$ & $-0.923^{* * *}$ \\
\hline & $(0.303)$ & $(0.283)$ \\
\hline Sector dummies & yes & yes \\
\hline Observations & 203 & 203 \\
\hline
\end{tabular}

Stepwise probit regression (with standard errors correction). The dependent variable is failure, a dummy variable equal to 1 if the firm ceased its activity for financial distress in the period between December 2012 and April 2014 and zero otherwise.

$* * *$ denotes significance at 1 percent level, $* *$ at 5 percent level, $*$ at 10 percent level. 